\title{
Reconnaissance Geophysical and Geological Studies on Bahrah Prospect, Makkah Al-Mukarramah Region, KSA
}

\author{
Mansour A. Al-Garni, "Hesham M. Harbi, \\ *Abdelmonem A. Eldougdoug, Hamdy I. Hassanein \\ and Hesham M. El-Kaliouby \\ Geophysics Department, * Mineral Resources and Rock Department, \\ Faculty of Earth Sciences, KAU, Jeddah
}

Received: 20/1/2008

Accepted: 27/4/2008

\begin{abstract}
The geological and geophysical studies carried out on the northern part of Bahrah prospect led to the recognition of a mineralized metarhyolite tuff zone (around $200 \mathrm{~m}$ wide and $700 \mathrm{~m}$ long) along the northern extension of the central gossan zone. This zone is characterized by the presence of exposed lensoid masses from metachert (siliceous gossan), massive and banded barite, and magnetite. IP and magnetic surveys along this zone proved the existence of a 40 meters deep anomaly that is open with depth and extends for about $200 \mathrm{~m}$ to the north along the strike. The surface barite mineralization is similar mineralogically and chemically to the blind ore encountered in a drill hole drilled about $250 \mathrm{~m}$ to the east of the central gossan zone. The exposed barite mineralization contains copper, lead and zinc with ratios greater than $1 \%, \approx 41 \%$ Barium, $\approx$ $21 \% \mathrm{MnO}$ and $\mathrm{Au}$ up to $13.5 \mathrm{~g} / \mathrm{t}$. It seems that there are two mineralized horizons with higher grades to the north. It is recommended to carry out further exploration to the north along the strike of the blind ore as well as the exposed barite mineralization.
\end{abstract}

\section{Introduction}

The Bahrah prospect is located approximately $45 \mathrm{~km}$ east of Jiddah on Makkah highway, and $3.5 \mathrm{~km}$ north of the highway via a desert track. The coordinates of the centre of the area are $21^{\circ} 2342^{\prime \prime N}$., 39 $33^{\prime} 35^{\prime \prime} \mathrm{E}$. (Quadrangle 21/39D). The approximate location of the prospect is shown in Fig. 1. The base elevation of the area is approximately $200 \mathrm{~m}$ a.s.l. The 
southern half of the prospect consists of sandy wadis and low hills, whereas northern half is relatively rugged.

Since the prospect discovery by Al Shanti 1967, the Bahrah gossaneous zones (Western (A) and Central (B), Fig. 1) were subjected to numerous geological and geophysical studies. Values up to $7.5 \mathrm{~g} / \mathrm{t} \mathrm{Au}$ and up to $1.5 \% \mathrm{Cu}$ were reported from samples collected from trenches dug on the western gossans. The central gossan is best exposed and extends over a distance of $\sim 2 \mathrm{~km}$. The northern segment is characterized by the presence of barite, malachite staining and manganese oxides. A grab sample from this segment was analyzed and was found to contain $2.27 \% \mathrm{Zn}, 0.67 \% \mathrm{~Pb}, 0.15 \% \mathrm{Cu}$ and $10 \% \mathrm{Ba}$ (Al-Shanti, 1969).

The Bahrah gossans were the subject of the M.Sc. thesis of Tofig (1977) and dealt with the southern extension of the gossaneous zone and reported the presence of pyritic mineralization with subsidiary chalcopyrite, barite and sphalerite. The northern end of the central gossan is associated with barite and specks of galena.

The interest was renewed in 1980's and geophysical surveys conducted by ARGAS (1983) and Last et al., (1985) led to the recognition of three conductors, designated as Western (A), Central (B) and Eastern. While the western and central conductors are associated with surface gossaneous exposures, the eastern conductor is associated with a blind ore body with no surface exposures. The northern segment of the central gossan was not surveyed geophysically.

The three conductors were drill-tested by Sanders and Abdulhay (1987) and geochemical analyses of the core samples were carried out. They concluded that both the central and western gossans are of low economic potential, while the eastern blind mineralization is of subeconomic grade (24 m and average $2.23 \% \mathrm{Zn}$ and $12.1 \mathrm{~g} / \mathrm{t} \mathrm{Ag}$ ) and there is a potential for grade increase along the strike of the mineralization. The results of the chemical analyses show that the mineralzation zone is associated with high values of $\mathrm{Ba}$ and $\mathrm{Mn}(>5000$ ppm) which can be used as a pathfinder for the mineralization. They recommended that there is a high chance of base metals mineralization north of their surveyed area. They concluded that the combination of both EM and IP yield the best results and recommended that further EM and IP surveys should be undertaken to improve the definition of the conductors associated with the sulfides mineralization (Sanders and 
Abdulhay, op. cit.). Jacques et al., (2000), conducted a stream sediments geochemical survey over the whole Bahrah metavolcanic belt. The collected samples were analyzed for $\mathrm{Zn}, \mathrm{Cu}, \mathrm{Pb}, \mathrm{Au}$ and $\mathrm{Ag}$. An area anomalous with $\mathrm{Zn}, \mathrm{Cu}$ and $\mathrm{Pb}$ was delineated along the northern extension of central gossan. When chemical analysis of the bed rock samples, given by Jacques et al., (op. cit.) was examined, it was found that the northern area along the strike of the central gossan is associated with anomalous $\mathrm{Ba}$ and $\mathrm{Zn}$ content.

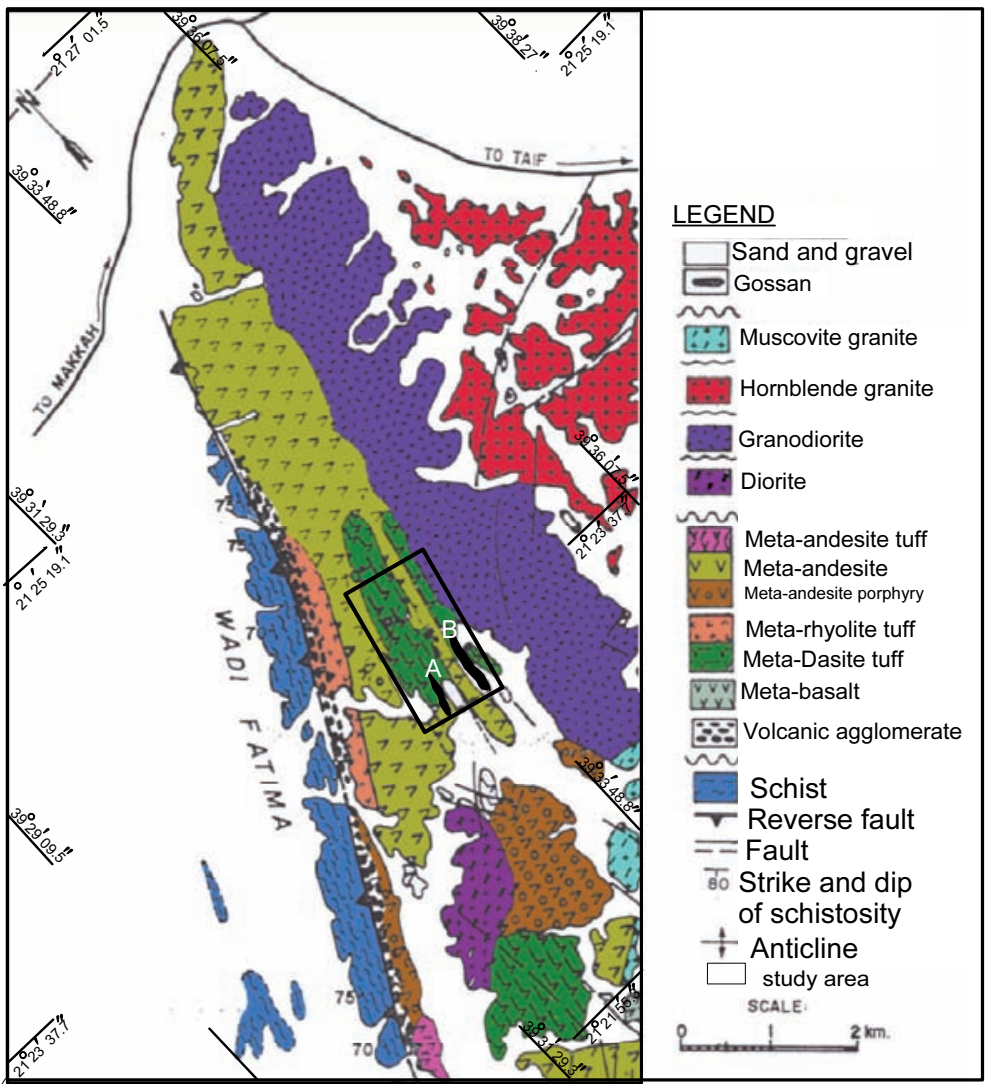

Fig. 1. Geological map of Bahrah prospect area (modified after Tofig and Al-Shanti, 1984).

Based on the data collected from drilling the eastern blind mineralization, $\mathrm{Ba}$ and $\mathrm{Zn}$ distribution in the surface bed rock samples and the analysis of grab samples reported by Al-Shanti (1969), the 
northern area was selected for a detailed geological and geophysical studies for the possible occurrence, if any, of a mineralization similar to that intersected by the hole drilled into the eastern conductor.

\section{Geology of Bahrah Prospect}

The prospect is located at the northeastern part of $3.8 \mathrm{~km}$ long X 2-3 $\mathrm{km}$ wide metamorphosed volcanic and volcaniclastic sequence of upper Proterozoic age along eastern side of Wadi Fatima (Fig. 1). The layered rocks of the metavolcanic sequence strike north and dip subvertically or steep to the west. The metavolcanic sequence is bounded on its western side by a schist belt trending NE and dips steeply to the west and shows well developed schistosity and tight isoclinal folding. The contact is a NNE trending high angle reverse fault dipping west (Tofig and AlShanti,1984).

The volcanic rock sequence is represented by metabasalt, metaandesite, metadacite metarhyolite and their volcaniclastic equivalents. These rocks were derived from a calc-alkaline magma with some tholeiitic affinities indicating a mature island arc setting (Tofig and Al-Shanti, 1984). The volcanicity in such tectonic setting is usually multicyclic with the andesite at the base of each cycle followed by a felsic sequence (host of the massive sulphide mineralization) at the top (Allen et al., 2002). They host two parallel gossaneous zones, namely; Western and Central. The gossan zones extend along strike for a distance of $\cong 1500 \mathrm{~m}$ with a width ranging between $10-20 \mathrm{~m}$. A $50-60 \mathrm{~m}$ oxidation zone overlies a primary sulfide mineralization consisting chiefly of pyrite and chalcopyrite with smaller amounts of pyrrhotite, sphalerite, galena and bornite and is believed to be syngentic volcanogenic (Tofig and AlShanti, op. cit.).

The stratigraphy and structure of the metavolcanic sequence was not studied in detail, but the part of the volcanic sequence associated with the Bahra gossaneous zone has been studied by Tofig and Al Shanti (1984) and Sanders and Abdulhay (1987). Tofig and Al Shanti (1984) stated that the central gossan dips east while the western gossan dips west and forming a northeast trending anticline. Sanders and Abdulhay (1987), based on a scarce facing structures within the layered volcanic sequence suggested a westerly younging sequence, from east to the west: metaandesite, metarhyolite tuff hosting discontinuous metachert 
lenses(central gossan), metadacite tuff, metarhyolite dome overlain by quartz-eye metarhyolite tuff which grades to highly altered and ferruginous metarhyolite tuff, and finally overlain by western gossan which is in turn overlain by metaandesite lava with metatuff intercalations.

The relationship between the metaandesite overlying the western gossan and the metaandesite underlying the central gossan is not clear. According to the interpretation presented by Sanders and Abdulhay (1987), it is possible that the metaandesite underlying the felsic rocks with the associated gossan represent one volcanic cycle while the metaandesite which overlies the western gossan form the base of another younger volcanic cycle. But, there is a possibility that the felsic rock sequence with the associated gossans belong to an older volcanic cycle with the metaandesite constitute the base of a younger volcanic cycle.

The NE extension of the metavolcanic belt at al Jamoom area was studied by Matsah et al. (2005), and they concluded that the area represents a NE trending shear zone. The shearing gave rise to an imbricate thrust stack which consititues a homoclinal NW dipping metamorphosed schists, marbles and volcaniclastics. Morover, the assemblage of structures display interlinked system of layer-parallel thrust and isolated coaxial SE-verging-folds. Later, cross cutting conjugate strike-slip sinistral faults trending NNW and dextral faults trending E-W that post-date both folding and thrusting.

The area under consideration could be visualized as an imbricate thrust stack accompanied by folding and later conjugate shear planes similar to the Al Jomoom area. It is worth mentioning that Last et al., (1985) recognized a conjugate set of faults (NW and E-NE trends) from magnetic survey of the area. Therefore, It seems that the metavolcanics and the schist belt of Bahrah area were subjected to a NW-SE directed compressional regime. The details of the structural elements within the metavolcanic belt which hosts the Bahrah gossaneous zones need to be unraveled.

To test these possibilities, an east - west traverse to the north of the area of the main gossaneous zone was studied in detail in the present project. The following is the succession of the rock types encountered along the traverse from the west to the east; brecciated metarhyolite, 
metarhyolite, quartz-eye metarhyolite tuff and metaandesite. The sequence strikes north with subvertical dipping. The brecciated rhyolite (Fig. 2) is located north of the metarhyolite dome described by Sanders and Abdulhay (1987) to the south and occupies an area about $300 \mathrm{~m} \mathrm{x}$ $200 \mathrm{~m}$.

The metarhyolite tuff is characterized by the presence of lensoid masses from the metachert (siliceous gossan) similar to those exposed along the southern extension of the central gossan, lenses and pods of banded and massive barite with disseminated sulphides(Fig. 3), malachite, and $\mathrm{Fe}$ and $\mathrm{Mn}$ oxides staining, and magnetite lenses and bands (Fig. $4 \& 5$ ). All these lenses are elongated parallel to the NNE striking foliations of the enclosing metarhyolite tuff. The metachert lenses occupy a stratigraphically higher level when compared to the barite and magnetite lenses (Fig. 6). The southern extension of the central gossan has been searched for possible occurrence of barite and magnetite lenses, Instead, massive pyrite rich metarhyolite lenses where found in close association with the metachert lenses (Fig. 7).

\section{Petrographic and Chemical Studies}

Representative samples were collected from the associated barite and Fe-Mn oxides mineralization for petrographic and chemical studies to define their mineralogical composition. Chemical analyses were carried out at ACME analytical laboratories, Canada, by ICP-ES technique and the results are given in Table 1 .

\section{Barite Mineralization}

The barite mineralization consists mainly of barite, magnetite, goethite and stained with malachite. The barite occurs as banded ormassive aggregates with disseminated magnetite (Fig. 8) which is altered to hematite (martite). Sometimes, magnetite occurs as bands (few cms thick) interbedded with barite dominated bands. Sulphides, mainly pyrite, were altered completely to goethite and sometimes present as relicts within goethite (Fig. 9). Goethite pseudomorph after pyrite shows Colloform texture and desiccation cracks with relicts from sulphides and $\mathrm{Au}$ (Fig. 10). Malachite as staining veinlets filling fractures is a common feature and encloses goethite pseudomorphs after pyrite. Chemically, this type of mineralization is characterized by high values $\mathrm{Ba}$ (up to $41 \%$ ), 
Mn (20.98\%) and base metals (Cu 320 - >10,000 ppm; Pb 3034 $>10,000 \mathrm{ppm} ; \mathrm{Zn} 330$ - >10,000 ppm). Since the analyzed samples were collected from surface exposures and have been subjected to oxidation and leaching (particularly $\mathrm{Zn}$ ), it is expected that the mineralization at depth will be higher in the base metals values.



Fig.2. Rhyolite Braccia, Northern area.

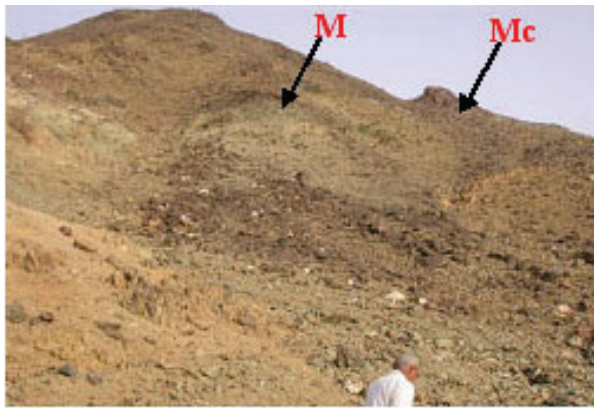

Fig.4. Metachert and magnetite lenses in the metarhyolite tuff, northern area; looking east.

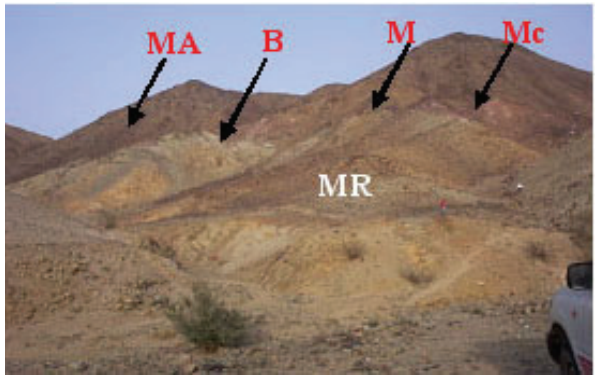

Fig.6. A view of the northern area showing the metachert, barite and magnetite lenses within the metarhyolite tuff with the metaandesite at the top. Photo looking east.

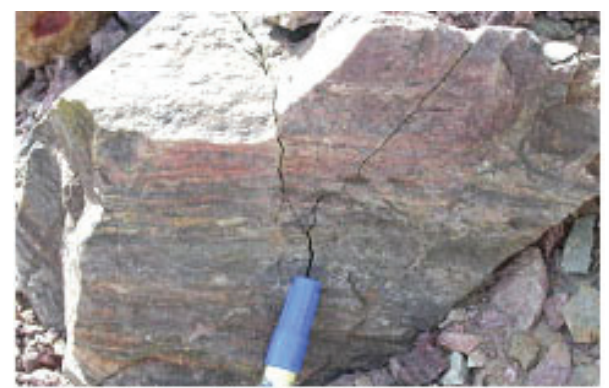

Fig.3. Banded Barite, northern area; looking east.

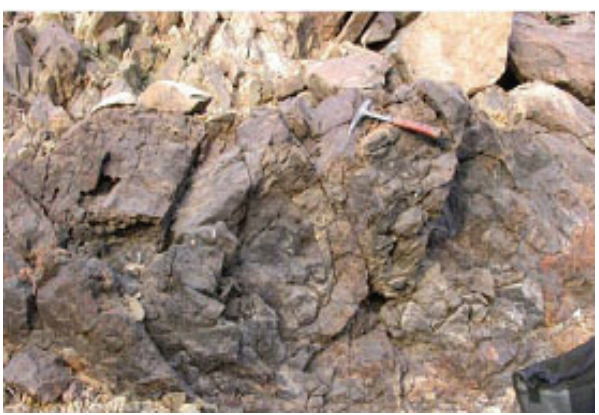

Fig.5. A magnetite lens within the meta-rhyolite tuff, northern area; looking east.

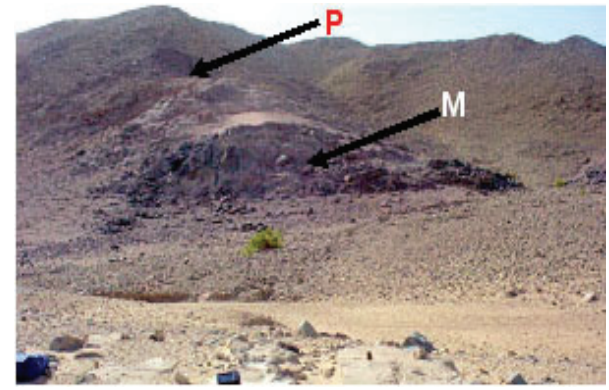

Fig.7. A metachert lens (M) and pyrite rich metarhyolite lense (P) in metarhyolite tuff; Southern extension of the central gossan. Photo looking west. 





The analyzed four samples show Au values up to $13.5 \mathrm{~g} / \mathrm{t}$ (13.5, 4.0, 1.2 and 0.2 ) and $\mathrm{Ag}$ values (range between 10-25 ppm with one sample higher than $100 \mathrm{ppm}$ ). The Au values are higher than those reported by Sanders and Abdulhay (1987) from the blind ore located about 250m east of the central gossan.

This Barite mineralization is comparable to the blind ore encountered in a drill hole located $250 \mathrm{~m}$ to the east of the central zone. Accordingly, the blind ore might represent another mineralized horizon within different volcanic cycle and should be searched for a possible extension to the north.

\section{Fe and Mn Oxides Mineralization}

This type of mineralization occurs as lenses (few meters in dimensions) within the meatchert, which is intercalated with the metarhyolite tuff and usually capping the barite mineralization. The high $\mathrm{SiO}_{2} \%$ as shown in Table 1 indicates that the mineralization is a siliceous or metarhyolitic tuff. Some of the lenses are massive magnetite (Fig. 11), hematite (Fig. 12) with variable $\mathrm{MnO}, \mathrm{Fe}_{2} \mathrm{O}_{3}$ contents as well as low base metal content ( $\mathrm{Cu} 4.3$ - 99, Average 30 ppm; Pb 13.3 - 211.6, Average 80ppm; Zn 52-2207, Average 530 ppm; Ag 0.5 - 26.6, Average 5; Au 8.2 - 348, Average $145 \mathrm{ppb}$ ). Some of the magnetite lenses are enriched in barite with Ba up to $6.6 \%$ (98.4 - 6596.2, Average 9700). The high $\mathrm{Ba}$ content is attributed to the close association with barite mineralization. These bands are enriched in $\mathrm{MnO}$ (up to 50\%) where they are traversed by maganosite $(\mathrm{MnO})$ veinlets.

\section{Pyrite Metarhyolite Tuff}

This type of mineralization was identified along the southern segment of the central gossan zone in association with the metachert. Pyrite occurs as euhedral disseminated crystals (Fig. 13) within the metarhyolite tuff (samples 11, 12 and 13). Chemically, these samples are characterized by low base and precious metals content ( $\mathrm{Cu} 431.6$ 1323.6 Average 680 ppm ; Pb 28.4 - 62.5, Average 50 ppm; Zn 6 -14, Average 4 ppm; Ag 1.4 - 5.1, Average 3 ppm; Au 159.8 - 534.6, Average $237 \mathrm{ppb}$ ). Ba content ranges between 225.8 - 1657 with an average $766 \mathrm{ppm}$. 
This type of mineralization was probably deposited at deeper reducing conditions and away from the barite mineralization with the assumption that the barite mineralization were deposited close to the site of discharge of volcanic exhalations enriched in $\mathrm{Ba}, \mathrm{Mn}, \mathrm{Cu}, \mathrm{Pb}, \mathrm{Zn}, \mathrm{Au}$ and $\mathrm{Ag}$ as suggested by the presence of the brecciaed metarhyolite tuff (vent breccias) underneath the barite mineralization. Such a model of deposition of this VMS needs to be verified by further studies.

\section{Geophysical Surveys}

The geophysical work in the present project is designed to emphasize already delineated locations of mineralization and to explore other new localities. Therefore, multiple-method geophysical surveys were conducted in the Bahrah prospect. The study includes total magnetic intensity, self potential (SP), induced polarization (IP) and transient electromagnetic (TEM) methods which are the best sophisticated geophysical tools for natural resources exploration. Figure 14 shows the selected locations of different geophysical surveys which were conducted in the present project.

\section{Magnetic Survey}

The aim of the ground magnetic survey conducted in the present study is to delineate the contact between different rock units especially under wadi alluvium, in addition to delineate any relation of the showings of mineralization with magnetic features. This relation is useful to study any other expected subsurface mineralization.

Before carrying out any total magnetic intensity survey, some considerations must be taken in account. One of these considerations is the strike of the targets which must be more or less perpendicular to the direction of profiles under survey, and the interval between stations of observations must be determined according to the expected width and depth of the targets if they are known, and other information about earth magnetic field, like inclination and declination which are useful in adjustment of instruments and data processing.

According to the above considerations, 5 parallel profiles were prepared in W-E direction perpendicular to the trends of the expected mineralized zones (Fig.14). The interval between stations of observations is $5 \mathrm{~m}$ along the profile. The five ground total magnetic field survey was 
conducted using a proton precision magnetometer (model G856, Geometric made). The extensions of these magnetic profiles were selected to explore any subsurface structures, which may be controlling the extensions of previously mineralized zones and their extensions. The profiles no. 1, 2 and 3 (Fig. 14) were conducted to follow up any subsurface extensions of the central gossans and the blind ore to the south of the area. The profile No. 4 was conducted across the described mineralizations at the northern part of the study area. The profile no. 5 was conducted across the wastern gossan zone to explore any subsurface mineralization. The total magnetic intensity data were represented against their locations as curves (Fig. 15: a, b, c, d \& e).

Along profile No. 1, negative magnetic anomalies, which may be related to subsurface mineralized structure, were recorded at both ends of the profile, the amplitude range of this anomalies are relatively high, therefore, these anomalies may be attributed to subsurface geological structure bounding both sides of the wadi in these zones. More investigation by other geological and geophysical techniques is needed to define the causes of these anomalies (Fig. 15a).

Also, the negative magnetic anomalies are recorded near both ends of the profile No. 2, at distances $50 \mathrm{~m}$ and $250 \mathrm{~m}$. The Western anomaly (at $50 \mathrm{~m}$ ) is characterized by low amplitude, therefore, it may be attributed to subsurface mineralization and related to the extension of the central gossan (Fig. 15c). The other anomaly (at distance $250 \mathrm{~m}$ of the eastern end profile) is characterized by relatively high amplitude, therefore, this anomaly may be related to subsurface mineralized structure. Although, e low range of magnetic intensity along profile No. 3 ranges between 40239 and $40272 \mathrm{nT}$ ), the negative magnetic anomalies were recorded in the western and eastern sides of the magnetic curve (Fig. $15 \mathrm{c}$ ).

The magnetic intensity variations along profile no. 4 point to various subsurface structural variation beneath its extension. The important anomalous zone along this profile is observed at the eastern side. This anomaly may be attributed to the extensions of the magnetite and barite outcrops which are recorded in this zone (Fig. 15 d). Along profile No. 5, three magnetic anomalies (1, $2 \& 3)$ were recorded, (Fig. 15e), the first may be related to the mineralization below the western gossans. The 
other two anomalies may be related to other subsurface mineralized structures to the west of the gossan zone.
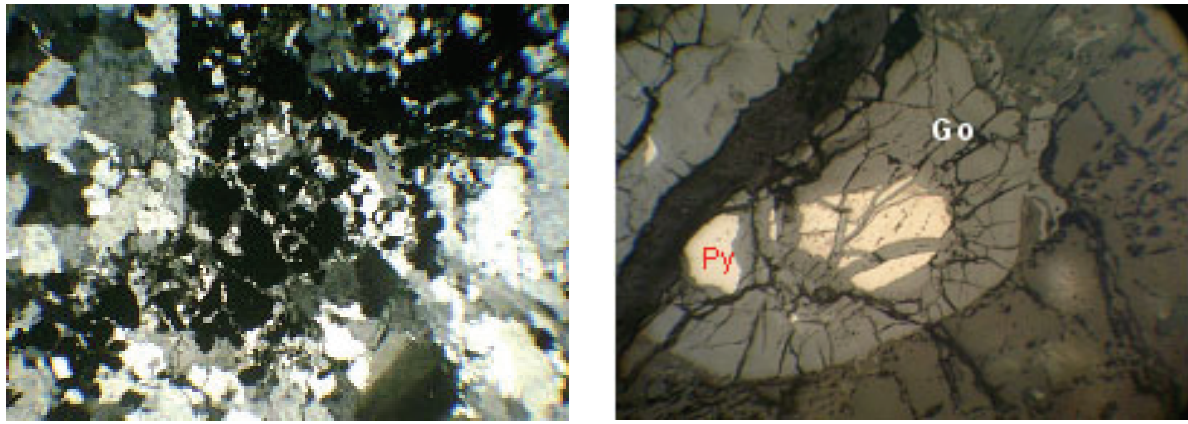

Fig. 8. Disseminated magnetite in massive barite, Fig. 9. Goethite (Go) replacing pyrite (Py) in T.S., C.N. 25X. massive barite, Polished mount, P.P.L., 25X.
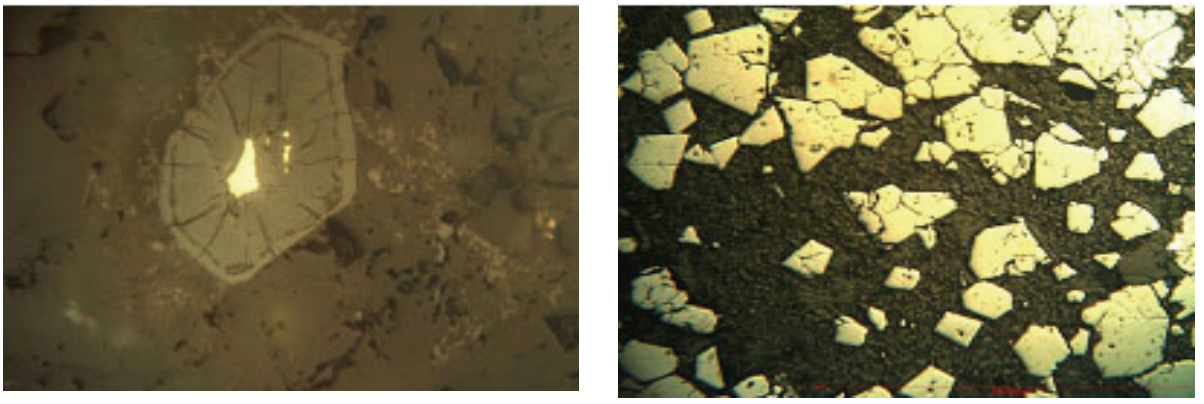

Fig. 10. Goethite pseudomorph after pyrite showing colloform texture and desiccation cracks with relicts from sulphides and Au

Fig. 11. Euhedral magnetite crystals in massive magnetite bands, P.T.S., P.P.L. in massive barite, Polished mount, P.P.L.
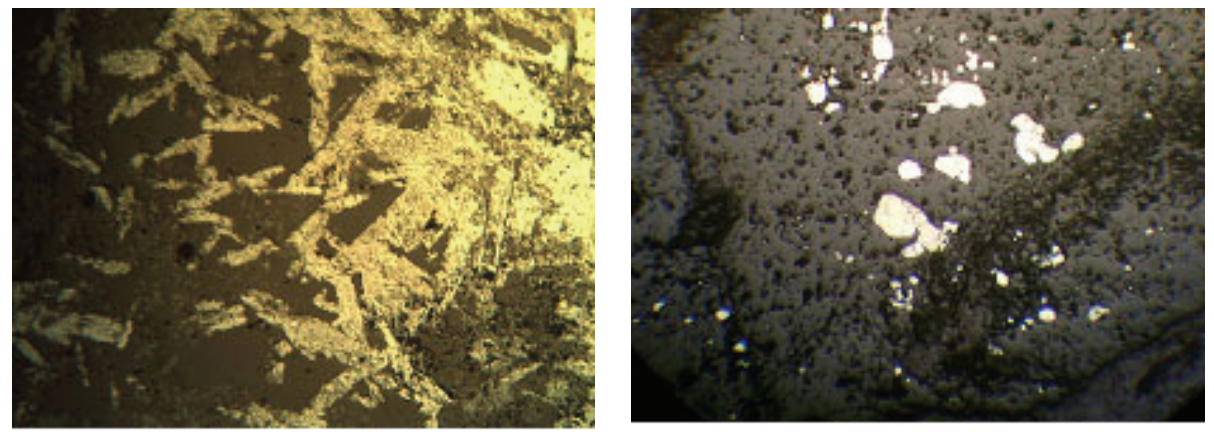

Fig. 12. Prismatic and needle-like crystals from hematite in massive hematite bands, Polished mount, P.P.L.

Fig. 13. Disseminated pyrite crystals in metarhyolite tuff, Polished mount, P.P.L., 25X. 


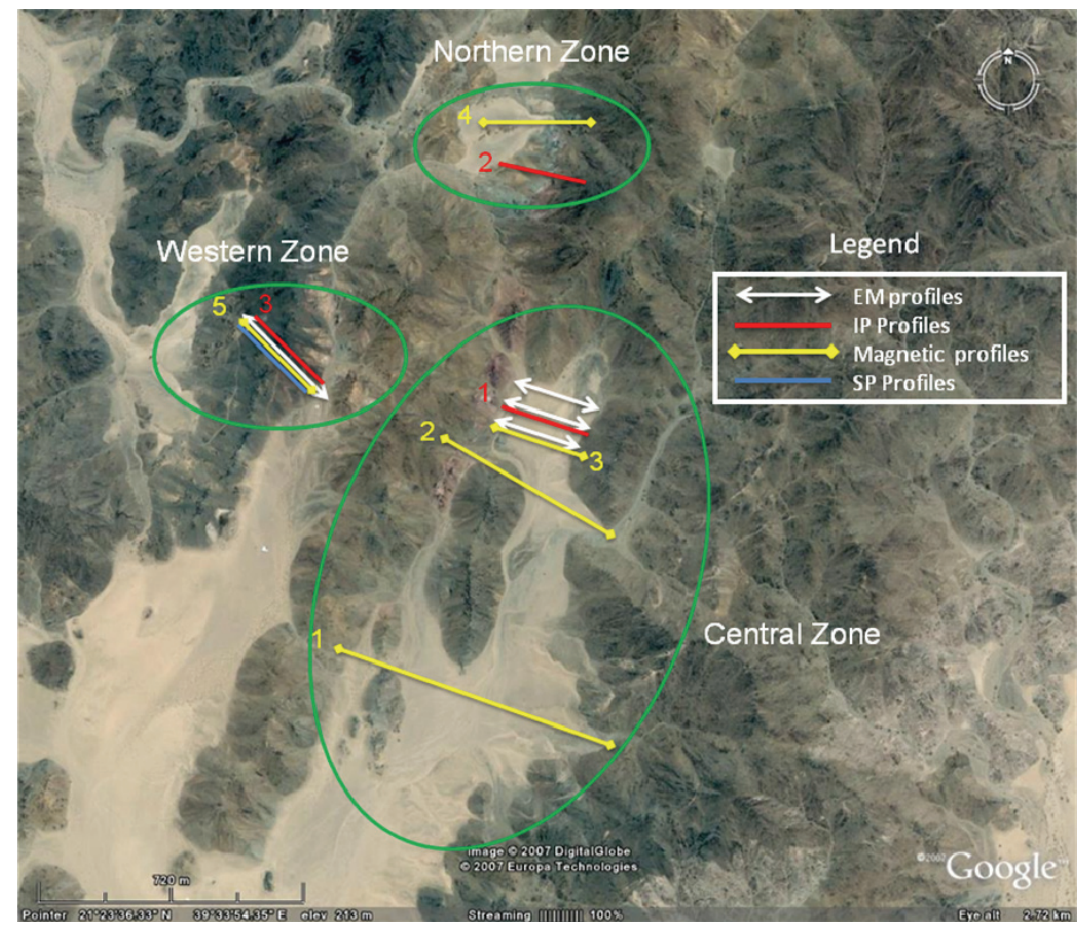

Fig. 14. Location map for the different geophysical surveys conducted in the study.

\section{Self Potential (SP) Survey}

The SP survey was conducted along one profile across the western zone using IRIS Syscal R2 resistivity meter (as a voltmeter) with nonpolarizable porous pots to avoid electrode polarization. The data was corrected, smoothed and presented as SP curve with distance. Figure 16 shows weak negative SP anomaly that reaches $(-35 \mathrm{mV})$ at station 130 associated with the western gossan zone.

\section{Transient Electromagnetic (TEM) Survey}

The principal aim of TEM method in this study is to find the occurrence and distribution of sulphides, based on the distribution of resistivity along the TEM profile. Four TEM profiles were conducted in the area, one at the western zone and three at the central zone to determine the electrical properties across the study area (Fig.14). Geonics 
EM57 transmitter, and a PROTEM receiver were used with a $1 \mathrm{~m}$ multiturn coil with a 100 square-meter area. The Geonics EM57 transmitter used to inject current ranging from 12-15 amps for the various soundings. The PROTEM receiver unit samples signal amplitudes over 20 gates during each measuring step, averaging the signal amplitudes in each gate over a specified duty cycles. The 20 gates width are distributed exponentially over a measuring time interval.

In the western zone, a large fixed transmitter loop with a small moving receiver loop was used. The transmitter is rectangular in shape with dimensions $300 \mathrm{~m} \times 200 \mathrm{~m}$, the long side was parallel to the strike of the gossans. The TEM profile was conducted nearly perpendicular to the gossans strike. Twenty-one stations were measured along the profile with a receiver station interval of $10 \mathrm{~m}$.

In the central zone, three East-West TEM profiles were surveyed between the central gossans zone and the eastern blind conductor perpendicular to the gossan strike. Each profile length is about $260 \mathrm{~m}$ across the wadi. The distance between the profiles is $50 \mathrm{~m}$ apart. A total of 75 stations were recorded (25 station at each profile) with station interval of $10 \mathrm{~m}$ along the profile. Two rectangular transmitter loops $(200 \mathrm{~m} \times 100 \mathrm{~m})$ were used in the present study with the long side parallel to strike of gossans.

The computer program IX1D developed by Interpex Ltd. (2007), was used to visually analyze the apparent resistivity data. The apparent resistivity data were plotted as a function of time on a log scale. Data points that deviated severely (a judgment decision) from the curve were deleted before inverse modeling. Inverse modeling, using the smooth modeling technique based on Occam's inversion principle (Constable et $a l .$, 1987), was used to estimate the geoelectric section for each sounding along the profile. The IX1D defaults were used for all smooth-modeling. A multiple-iteration smooth-model inversion was computed until the root-mean-square error reached an acceptable limit. The smooth-model inversion technique minimizes model roughness subject to the constraint that the model fits the data to a desired tolerance (Interpex Ltd., 2007). 


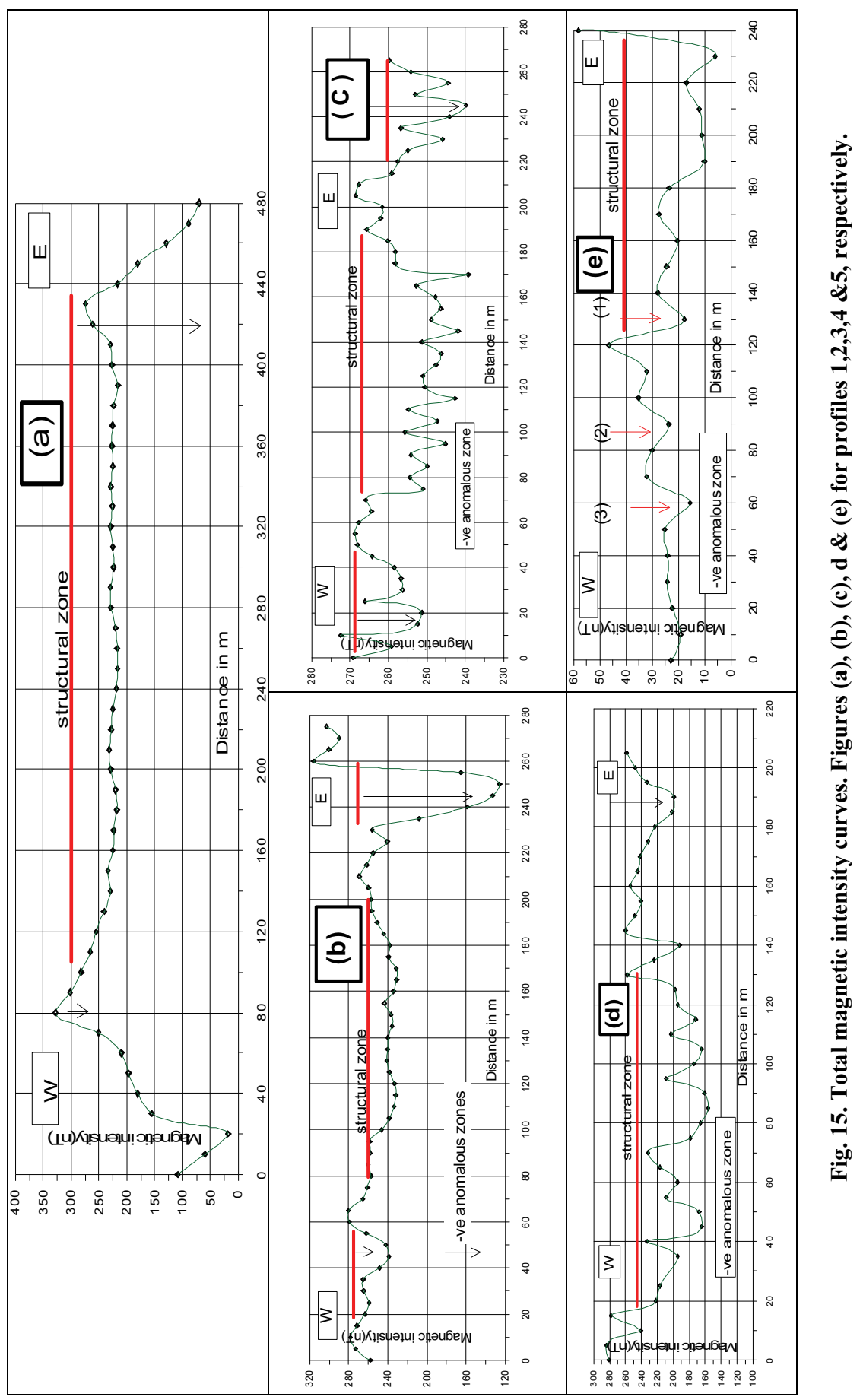


W

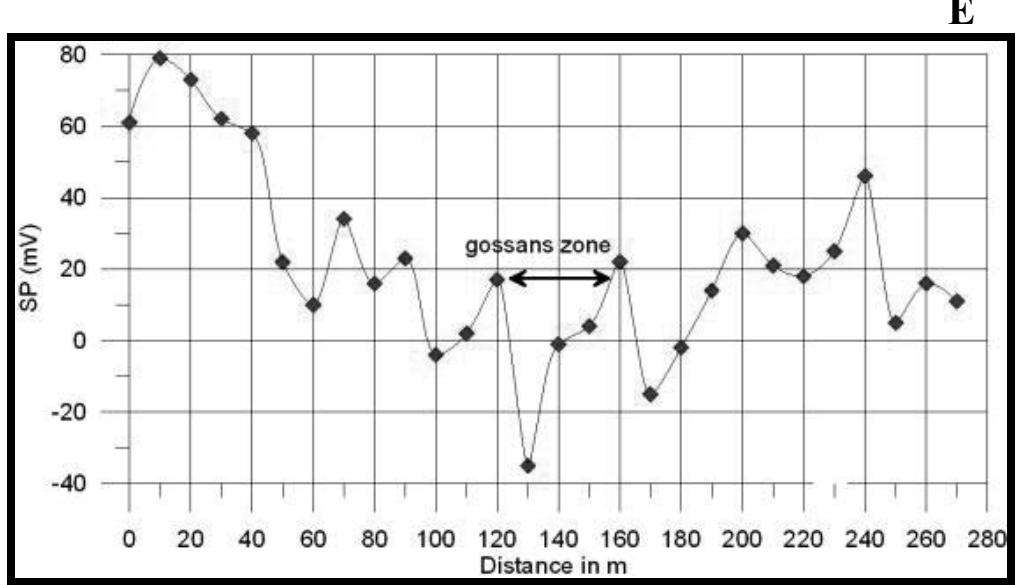

Fig.16. A self-potential curve along the profile extended across the western gossan zone.

The smooth-model inversion results of each sounding collected in the study area produced models at each sounding site showing the resistivity distribution with depth. To depict the spatial changes in resistivity based on the smooth-model inversion results, a two-dimensional profile of the TEM soundings was created.

In the western zone, Fig. 17a shows a low resistivity zone at depth in the range $50-100 \mathrm{~m}$ from the surface which may be attributed to the presence of deep mineralization, possibly sulfides.

Three profiles were conducted across the central zone and the blind conductor. In the southern profile (Fig.17b), there are three low resistivity zones. The first, at a depth of about $100-120 \mathrm{~m}$ and distance $180-230 \mathrm{~m}$, the second, at depth 60-100 $\mathrm{m}$ and distance $120-180 \mathrm{~m}$, and the third, at the western side at a depth of about $100 \mathrm{~m}$. The middle profile (Fig. 17c) shows a low resistivity zone at the eastern side at depth 50-120 m. The northern profile (Fig.17d) shows a moderate resistivity at the western side.

\section{Induced Polarization (IP) Survey}

The aim of using the IP survey is to locate the highly mineralized zones, which show high chargeability, and to distinguish between the massive and disseminated sulphides. IP time-domain system (ELREC-T, IRES-made) was used for conducting the IP survey. 
In the present work, three IP profiles were conducted (Fig.14). The dipole spacing used in this study was $10 \mathrm{~m}$. The first IP profile (across central gossan zone) was $260 \mathrm{~m}$ long. The second IP profile (across the mineralized zone at the northern part of the study area) was $270 \mathrm{~m}$ long. The third IP is $200 \mathrm{~m}$ length and extended perpendicular to the western gossan zone.

\section{-The Central Zone (Profile No.1)}

The electrical resistivity pseudosections (Fig. 18 a $\&$ b) along profile no.1 (central zone) show the following:

1- The upper part of the pseudeusection along the profile is considered as a relatively high resistivity area, which is related to wadi alluvium.

2- At the eastern part of the profile, distinctive anomalous zone is observed at depth about $45 \mathrm{~m}$, between station 190 to 210 , the value of chargeability reaches $27 \mathrm{mv} / \mathrm{sec}$. This distinctive zone and the high chargeability trend may be related the eastern blind ore (Sanders and Abdulhay, 1987) .

3-At the western part of the profile, there are three local high chargeability zones, these zones may be related to the primary mineralization below the gossan.

-Northern Part (Profile No.2)

The electrical resistivity pseudosections along profile no. 2 show the following:

1- The resistivity pseudeusection (Fig. 19 a \& b) shows anomalies of elongated shape characterized by high and low resistivity running nearly vertical across the section, these anomalies point to the variation in mineralization beneath this profile.

2- The eastern part of the profile shows a distinctive anomaly $20 \mathrm{~m}$ deep and is opened with depth beneath the station $220 \mathrm{~m}$. This zone is characterized by high chargeability indicating that the causative body of this anomaly is highly mineralized. 


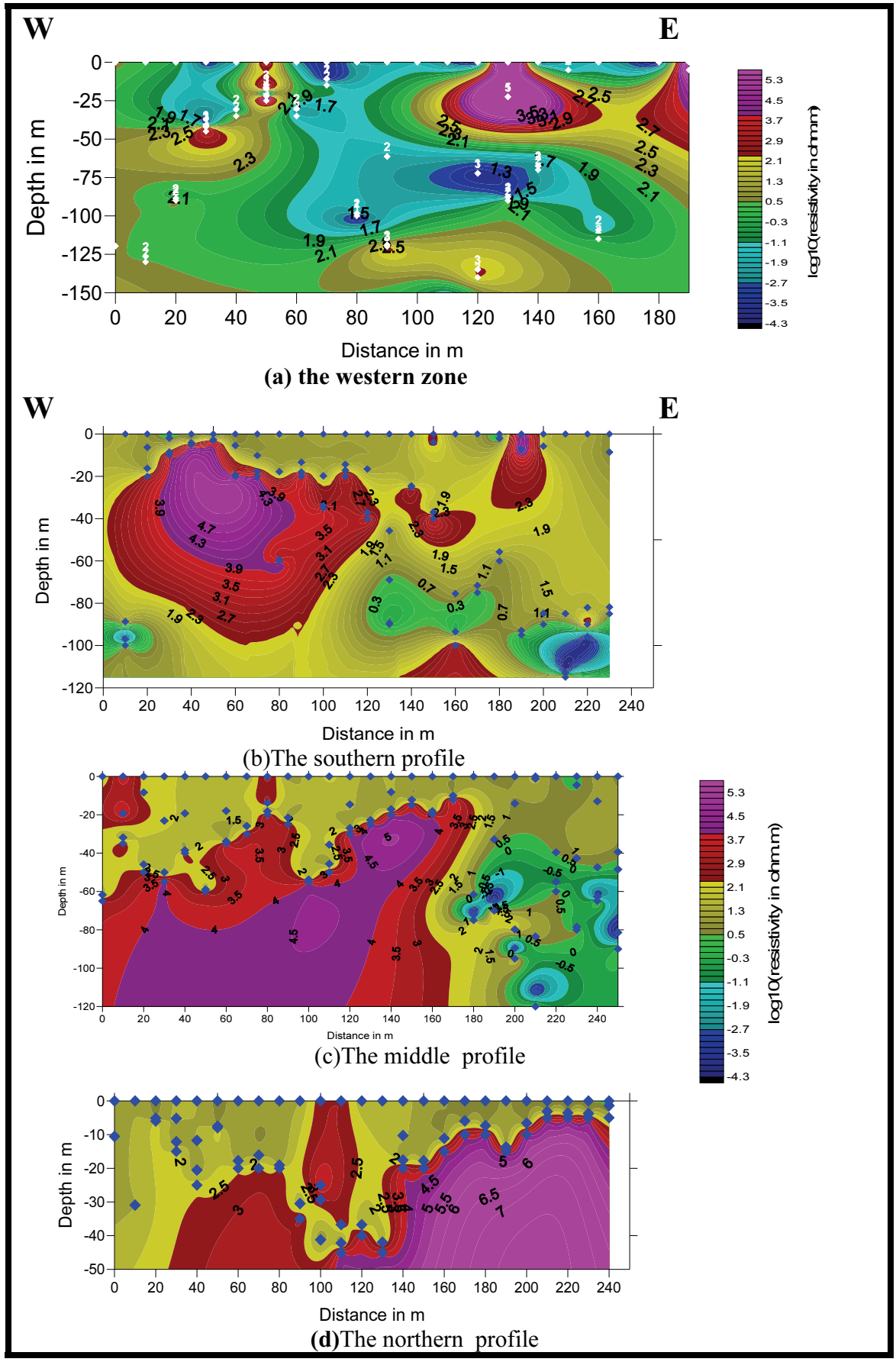

Fig. 17. Two-dimensional resistivity sections of the TEM sounding profiles. (a) across the western zone, (b),(c) \& (d) across the central zone. 


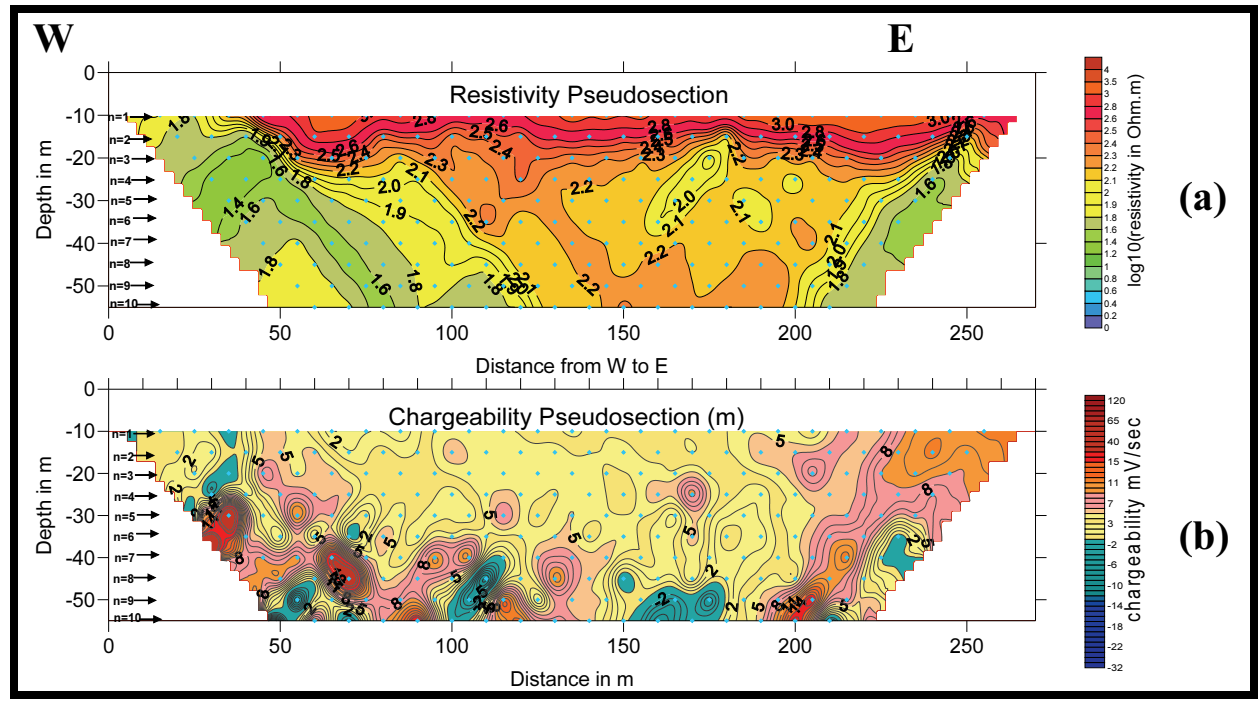

Fig. 18. IP Pseudosections across the middle profile of the central gossan zone.

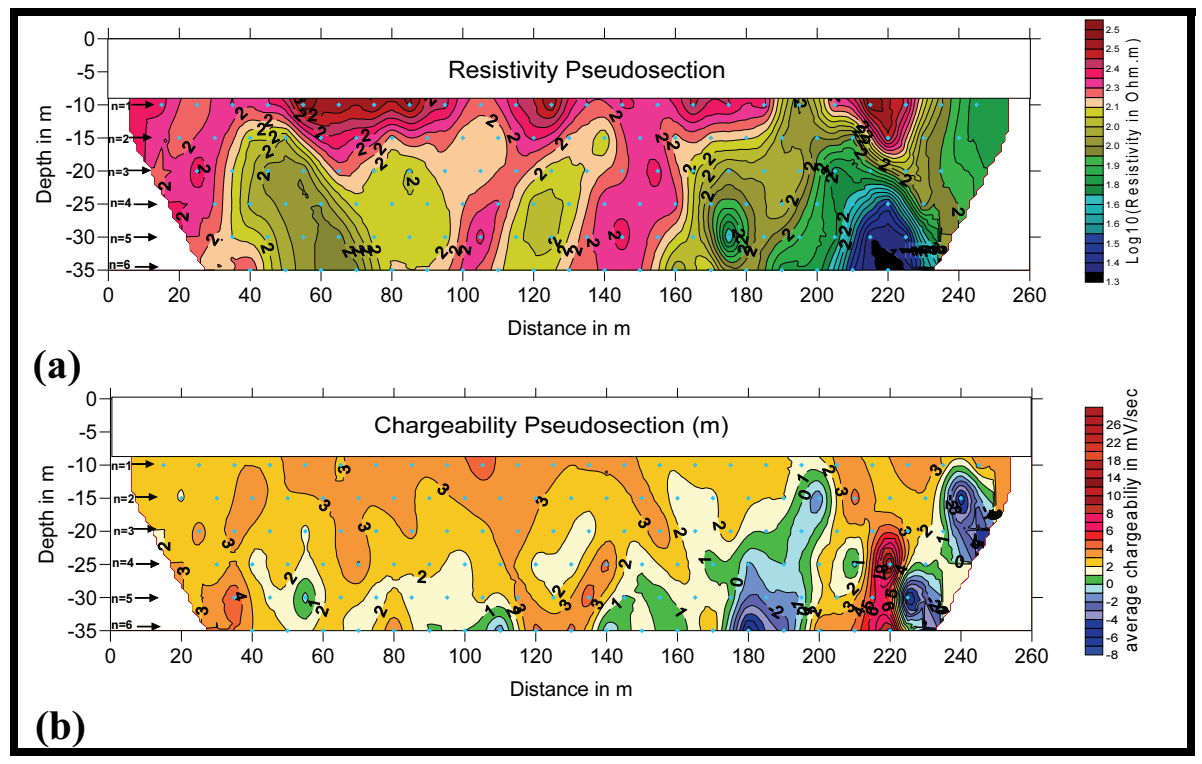

Fig. 19. IP Pseudosections across the northern part of Bahrah prospect. 
-The Western Zone (profile no.3)

Figure $20(\mathrm{a} \& \mathrm{~b})$ delineate that there are distinctive zone of anomalous resistivity and chargeability. The values of apparently resistivity decrease to $<10 \mathrm{Ohm} . \mathrm{m}$ at the zone between 70 and $110 \mathrm{~m}$ (Fig. 20 a). Two distinctive high chargeability anomalies were encountered at depth $>30 \mathrm{~m}$ and distance $60 \mathrm{~m}$ and $90 \mathrm{~m}$. In addition, a third anomalous at depth of about $20 \mathrm{~m}$ and $80 \mathrm{~m}$ distance (Fig. 20b) was encountered.

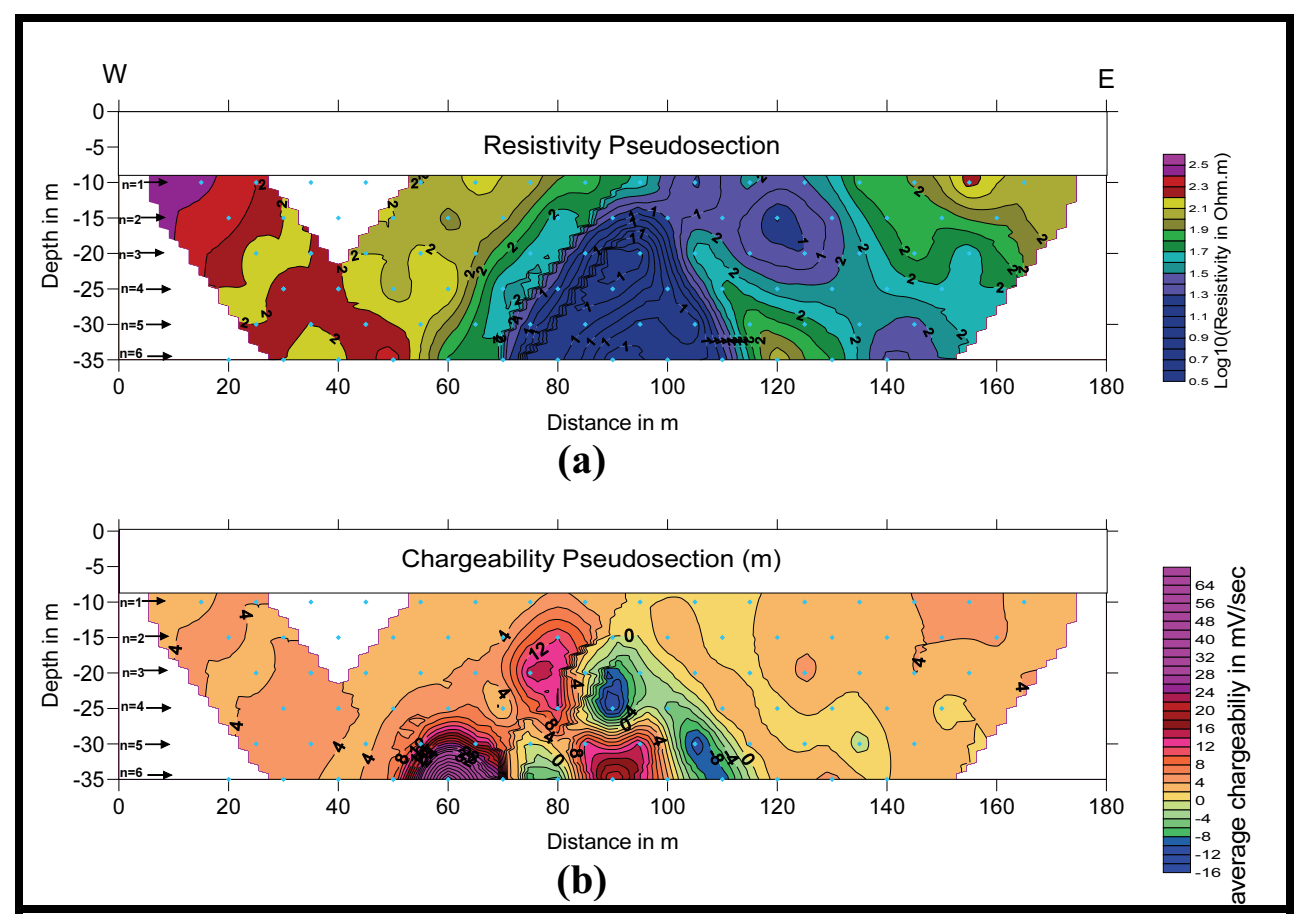

Fig. 20. IP Pseudosections across the western gossan zone.

\section{Results}

Geophysical surveys were conducted in the southern (western and central zones) and the northern parts of the Bahrah prospect. The latter was not studied in the previous geophysical surveys. 


\section{Western Zone}

Ground magnetic, SP, TEM and IP geophysical methods were conducted along one profile across the observed gossan which extends in NNE direction (Fig. 14), the integration of the results of these methods led to the following interpretation ( Fig. 21):

The total magnetic intensity curve along the profile shows two distinctive zones. The eastern part shows a wide low magnetic intensity. This zone may be due to subsurface structural feature or a contact between two different rock units. The middle is related to a fault zone, which probably affected the western gossan (anomaly no. 1, Fig. 21a). In addition, two anomalies ( 2 and 3 ) are recorded beneath the location 60 and $90 \mathrm{~m}$ west of the surface gossans. These anomalies may be related to a subsurface mineralization beneath these locations.

The low amplitude of the SP anomaly $(-35 \mathrm{mV})$ of the SP curve (Fig. $21 \mathrm{~b})$ along the SP profile indicates that most of mineralized intervals lie at depths higher than the depth of penetration of SP method, therefore, this method was not conducted in the other zones of the study area. Other low SP anomalies west of the surface gossan zone may be related to possible mineralization at depth. This matches well with the magnetic anomalies ( 2 and 3 ) along the magnetic profile.

Transient Electromagnetic TEM survey shows three conductive zones. One is recorded to the west between location 15 and $35 \mathrm{~m}$ at a depth of $\cong 40 \mathrm{~m}$. The second conductive zone extends to a depth of about $100 \mathrm{~m}$ beneath the distance between $55 \mathrm{~m}$ and $85 \mathrm{~m}$. The shallow part of this anomaly was confirmed by the IP method at the same location. These zones are related to the observed surface gossans. The third one lies between $60 \mathrm{~m}$ and $90 \mathrm{~m}$ depth beneath the distance between location 100 and $145 \mathrm{~m}$ along the profile (Fig. 21c).

The resistivity and chargeability pseudosections (Fig. 21d\&e) show three anomalous zones, one is related to the known surface gossan, at distance between $65 \mathrm{~m}$ and $80 \mathrm{~m}$ at 20 meters depth. The other two are related to another separated mineralized zone at depth or the extension of the first anomalous zone. They are located at the same depth $(>35 \mathrm{~m})$ between $45-75 \mathrm{~m}$ and $85-95 \mathrm{~m}$. 
The correlation between resistivity and chargeability curves shows that the site at $85 \mathrm{~m}$ from the west is recommended for an exploratory drilling to depth more than $100 \mathrm{~m}$. More exploration is needed to define the horizontal and vertical extension of the mineralized zones. Therefore, more detailed TEM \& IP surveys should be conducted across the observed and interpreted zones of mineralization.

\section{Central Zone}

Three geophysical exploration profiles were conducted to cover this area. Magnetic and TEM surveys (Fig. 22) along the southern profile, IP $\&$ TEM (Fig. 23) along the middle profile and TEM survey along the northern profile of the central zone (Fig. 17d).

The following is a brief discussion of the results of these surveys:

2.1. Southern profile: Total magnetic results along this profile show three different zones with distinctive magnetic signatures, two of them are low magnetic intensity at the two ends of the profile. The third covers a wide distance in the middle of the profile and may be related a certain fault or a contact between two different rock types (Fig. 22a).

TEM results show three conductive zones beneath this profile (Fig. $22 \mathrm{~b})$. One to the west at $10 \mathrm{~m}$ distance with a depth of $100 \mathrm{~m}$. The other two conductive zones are in the eastern part of the profile beneath the distance range 130-170 m and 200-230 respectively, at depth of about $100 \mathrm{~m}$. The last one continues to the east and is related to the blind ore defined by Sanders and Abdulhay (1987).

2.2. Middle profile: TEM Results show two distinctive zones. The eastern one has a low resistivity character with a number of anomalous low resistivity zones below $60 \mathrm{~m}$ depth. In this zone, three significant conductive zones are recorded beneath the distance from $175 \mathrm{~m}$ to $200 \mathrm{~m}$ at $70 \mathrm{~m}$ depth, and between the distance from 230 to $250 \mathrm{~m}$ at a $60-80 \mathrm{~m}$ depth and the third between the locations 190 and $220 \mathrm{~m}$ at $90-110 \mathrm{~m}$ depth (Fig. 23a).

The structure or the different lithology contact shown on the magnetic profile (Fig. 22a) is clearly present in the TEM profile (Fig. 23a) where the metavolcanics and the associated mineralization, located on the eastern side of the profile, are in direct contact with the high 
resistivity body (possibly diorite) exposed on the surface east of the profile.

IP Results at the western part of the profile show two significant local high chargeability zones (Fig. 23b\&c). The first lies between the surface gossans. At the eastern part of the profile a significant high chargeability zone is recorded between the distance 90 and $210 \mathrm{~m}$ at depth $50 \mathrm{~m}$ beneath the surface, and is associated with the blind ore.

The eastern part of the chargeability and resistivity pseudosections (Fig. $23 \mathrm{~b} \& \mathrm{c}$ ) shows a high chargeability relative to the resistivity and this indicates that the blind ore is massive. In the western side of the profile, the resistivity is high relative to the chargeability and this is attributed to the disseminated nature of the mineralization and/or oxidation. distance 25 and $45 \mathrm{~m}$ along the profile at depth $30 \mathrm{~m}$, and the other one lies at the distance between 60 and $70 \mathrm{~m}$. These zones are related to The correlation between the TEM and IP results emphasize the mineralization occurrence in the eastern side of the profile at depth between 50 to $120 \mathrm{~m}$ with a $70 \mathrm{~m}$ width and continue downward and extending to the east. The oxidation zone overlying the massive mineralization is about $40-50 \mathrm{~m}$ thick as evident from the higher resistivity interval above the low resistivity horizon (Fig. 23a and b).

It is recommended to drill a deeply inclined hole to the east in order to intersect the primary mineralization. It seems that the hole drilled by Sanders and Abdulhay (1987) with 45 degree inclination to the east was within the oxidation zone as no supergene minerals (such as chalcocite or covellite) were identified in the studied drill cores.

2.3. Northern profile: one TEM profile was conducted across the northern part of the central area. The results do not show any significant conductive anomaly (Fig. 17d). No mineralization was recorded probably because of the very small thickness of the metavolcanics hosting the mineralization which is underlain by the diorite intrusion.

\section{Northern Zone}

Total magnetic results show a significant anomalous magnetic zone at the eastern end of this profile between the distance $160 \mathrm{~m}$ and $210 \mathrm{~m}$ (Fig. 24a). 


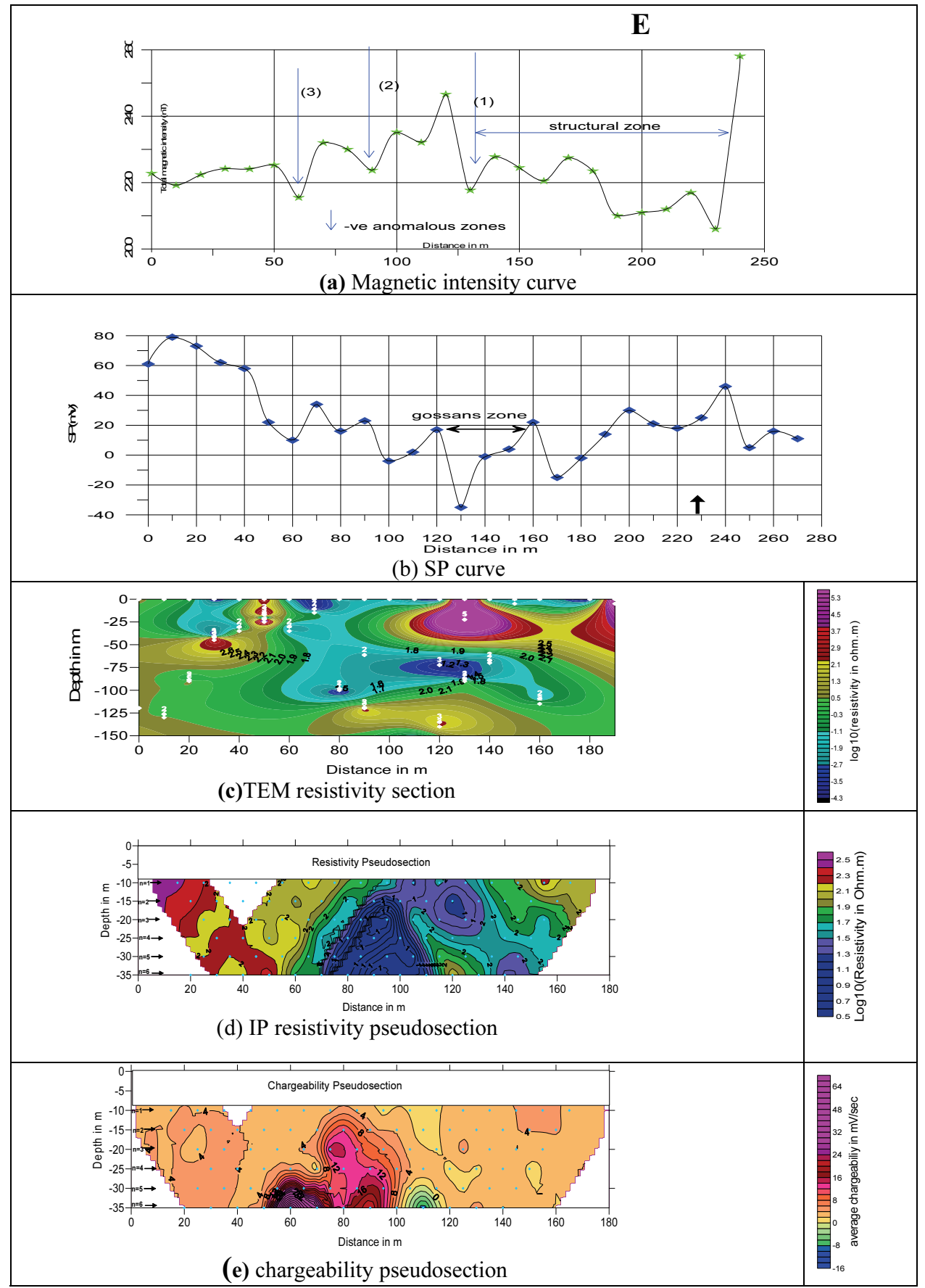

Fig. 21. Correlation between different geophysical surveys of the western gossan. 


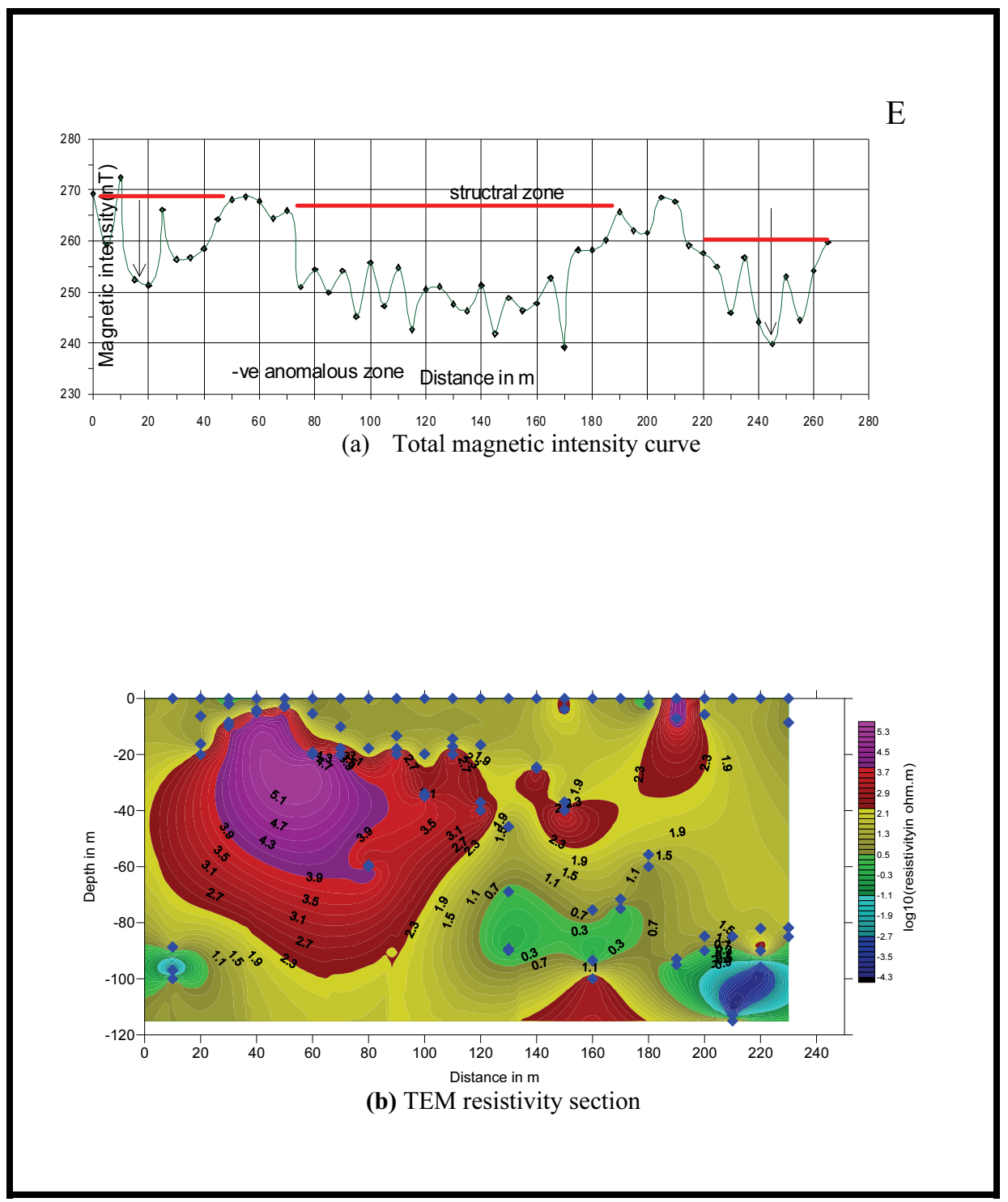

Fig. 22. Correlation between the results of both magnetic and TEM surveys conducted across the southern profile of the central zone.

Induced Polarization (IP) profile was conducted $200 \mathrm{~m}$ south of the magnetic profile (Fig. 24). At the eastern end of this profile, a significant 


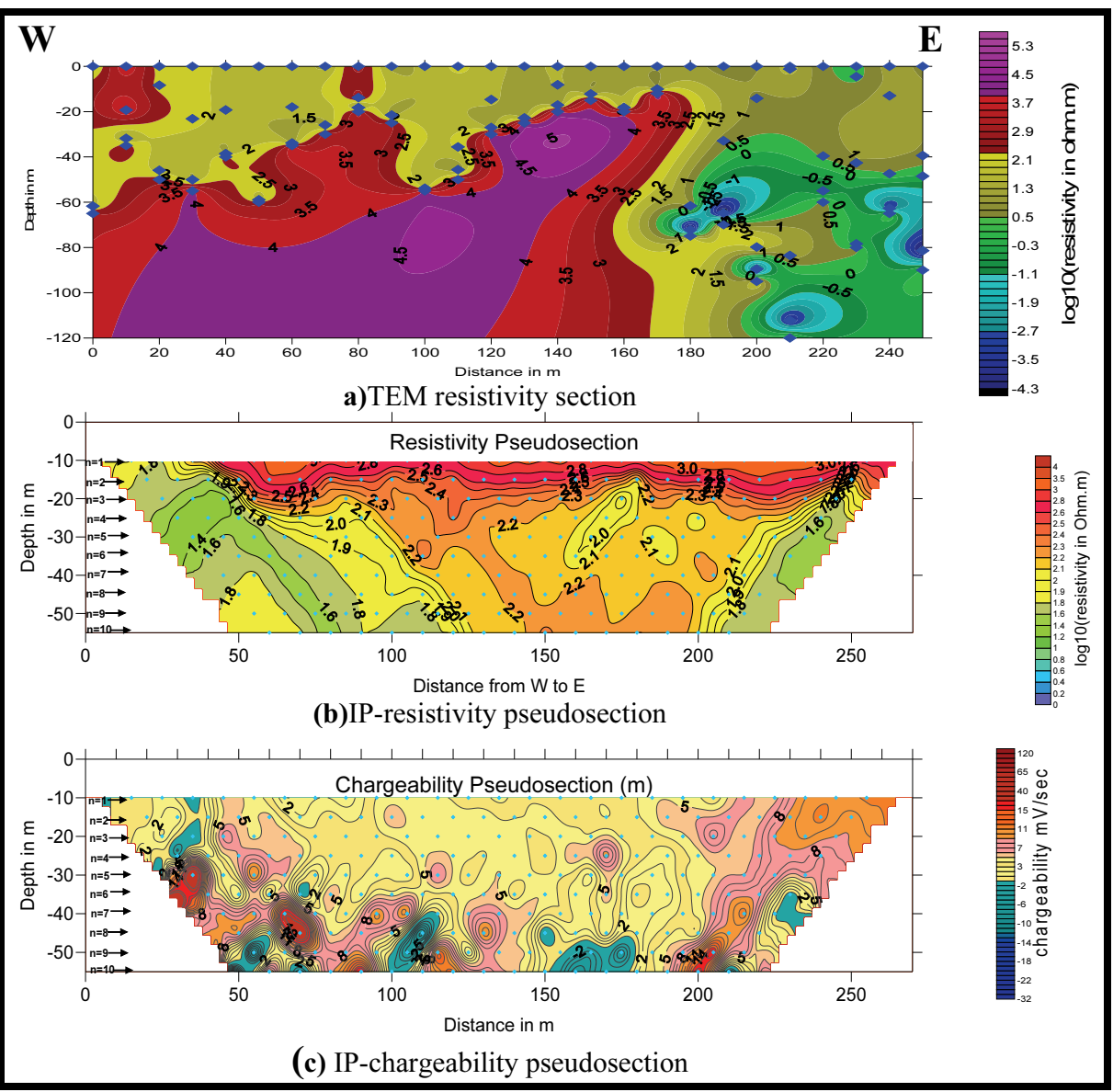

Fig. 23. Correlation between the geophysical survey results of the middle profile, central gossan zone.

Both the magnetic and IP profiles emphasize the occurrence of the mineralization between the two profiles and its possible extension (about $200 \mathrm{~m}$ northward) where magnetite lenses are exposed. IP (chargeability) anomaly is recorded beneath the distance between 215 and $225 \mathrm{~m}$ at $35 \mathrm{~m}$ depth (Fig. 24c). The mineralized body behind this anomaly may extend to a greater depth. The low resistivity and high chargeability (Fig. 24 b \& c) at this zone may be due to a massive nature of the mineralized body. Therefore, more geophysical investigations (TEM) are recommended to define the downward extension of this body with depth. 


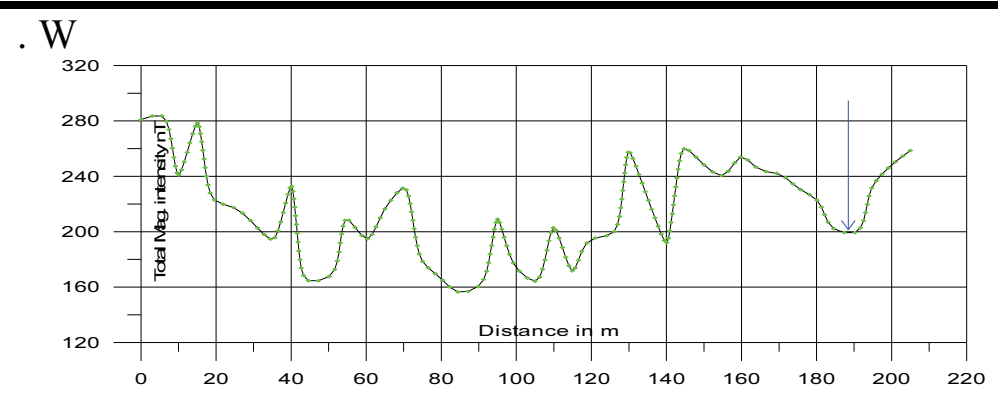

$\mathrm{E}$

(a) Magnetic intensity curve

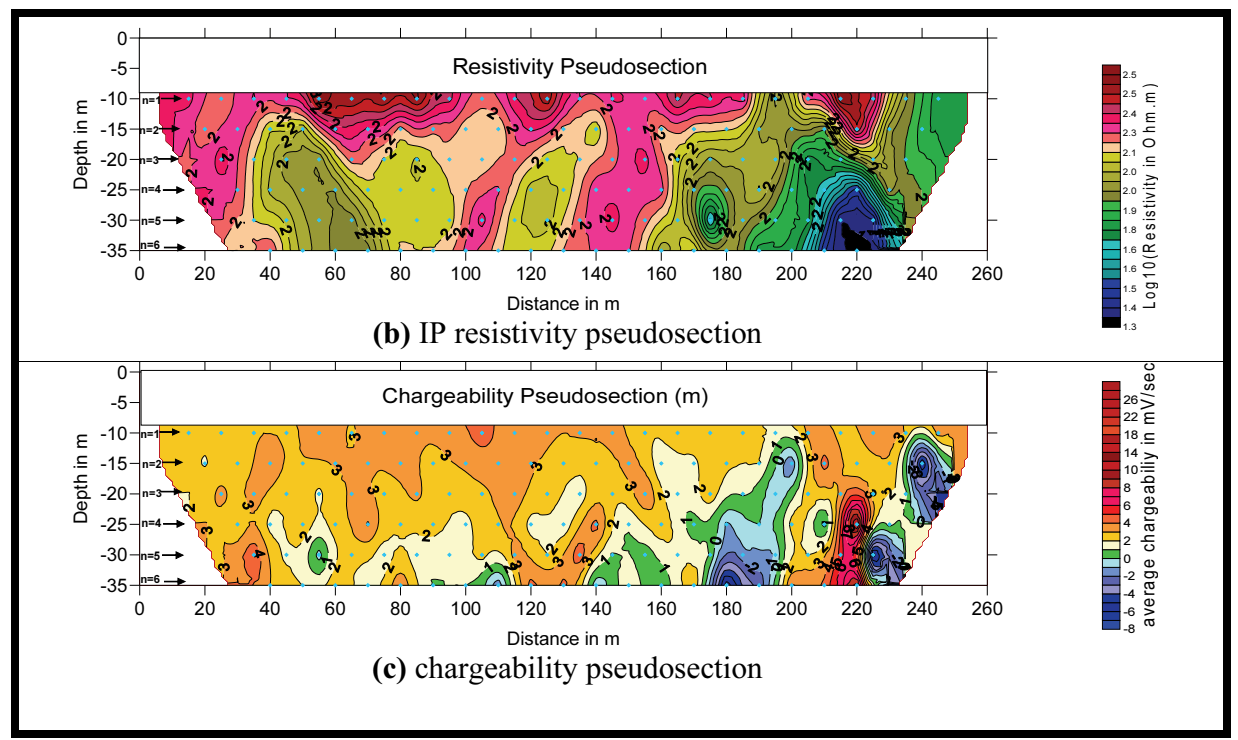

Fig. 24. Correlation between the geophysical survey results of the profile, northern part.

\section{Discussion and Conclusions}

The Bahrah area is known for the occurrence of two gossanous zones Western and central (Alshanti, 1969). Three conductors were delineated by previous geophysical surveys; two are associated with the western and central gossans while the third conductor is related to a blind ore zone to the east of the central gossan. The blind ore is of sub-economic grade $(\sim$ $24 \mathrm{~m}$ at $\sim 2.23 \% \mathrm{Zn}$ and $12.1 \mathrm{~g} / \mathrm{t}$ silver, no ore reserve estimation was 
carried out) and is characterized by high values (>5000 ppm) for Mn and Ba (Sanders and Abdulhay, 1987).

Bedrock samples collected by Alshanti (1969), Tofig (1977) and Jacques et al., (2000) from the area located to the north of the central gossan shows high $\mathrm{Ba}$ as well as $\mathrm{Zn}$ values. Accordingly, geophysical surveys (magnetic and IP) were conducted in the northern area because it was not explored in the previous geophysical studies.

The metarhyolite tuff from the northern area of the present study was found to contain lensoid masses of barite and magnetite in addition to metachert (siliceous gossan). These features point to the possible occurrence of a mineralization similar to the one intersected by the hole drilled into the eastern blind conductor.

The data obtained after geophysical field work using different methods of exploration, ground magnetic survey, SP, TEM and IP indicate that the prospect area is characterized by very complex subsurface structural features. The data show regional and local anomalous values. The regional anomalies are related to the surface and subsurface variation in lithological units and their contacts. The local anomalous values correspond to the exposed gossan zones and the blind eastern mineralization. The total magnetic data of the E-W profile across the western gossan zone reveal a negative week anomalous zone near the western end of the profile. The other four magnetic profiles were conducted along selected traverses across the central and the eastern mineralized zone. Three of these four magnetic profiles, show negative anomalous values at the eastern end correlatable with the blind mineralization. The data of the fourth profile don't show any reasonable variation.

The measured TEM data indicates that there are low- resistivity readings above the western gossans, a shallow anomaly beneath the 15 $35 \mathrm{~m}$ distance and about $40 \mathrm{~m}$ depth, and a deeper anomaly beneath the distance $55-140 \mathrm{~m}$ and a depth greater than $60 \mathrm{~m}$. The three profiles performed across the central gossan and the eastern (blind conductor) zones show a high conductivity at both ends of the profiles particularly the eastern end which corresponds to the blind conductor described by Last, et al., (1985). 
SP measurements along the western gossans delineate a weak negative SP anomaly correlated with the mineralized zone. Because of the limited depth of penetration of SP method (about $30 \mathrm{~m}$ ) which is still within the oxidation zone that extends down to $50-60 \mathrm{~m}$ as mentioned by (Tofig and Al-Shanti, 1984) and the presence of causative body at a greater depth $(>60 \mathrm{~m})$ as indicated by the TEM data, the SP method was not used in other locations.

IP method is applied along three profiles, the first across the central and the eastern blind mineralization, the second across the northern extension of the central zone and the third across the western zone. IP results along the first and third profiles show a number of zones of high chargeability which correlate with the location of the previously known zones of mineralization. The IP data along the second profile point to a new mineralized location at the eastern end of this profile which extends along a strike distance of $200 \mathrm{~m}$ to the north and at $40 \mathrm{~m}$ depth and continues downward.

The geophysical studies conducted in the present study led to a better understanding of the anomalous zone in the southern part of the prospect and the delineation of a mineralized zone in the northern part of the prospect. The combination of the TEM and IP method prove to be more efficient in delineating the mineralized horizons.

The mineralogical and chemical similarly of the surface barite mineralization exposed, in the northern part of the prospect to the blind ore located about $250 \mathrm{~m}$ to the east of the central gossan zone suggest that the two mineralizations belong to different mineralized horizons striking $\mathrm{N}-\mathrm{S}$. These two horizons need to be explored in detail particularly the northern extension to get a better picture of the subsurface distribution of the mineralization.

\section{Recommendations}

It is recommended to carry out more geophysical surveys (TEMand IP) along the northern extension of both the surface barite mineralization and the blind ore in order to delineate the extension of the mineralization. Drilling is recommended through a drill hole deeply inclined to the east to test the results of the geophysical survey conducted in the present 
project. Detailed field and structure studies are important to determine the relationship between the two mineralized horizons.

The area west of the western gossan zone need to be surveyed in detail for possible mineralization in the light of the TEM and IP results which point to the presence of anomalous horizons.

\section{Acknowledgement}

The authors would like to thank Prof. Ahmad Al-Shanti, Faculty of Earth Sciences, King Abdulaziz University for his support during the field work of this study and valuable discussions. This work was supported and funded by the Deanship of Scientific Research (Project No. 201/427) King Abdulaziz University, KSA.

\section{References}

Allen, R.L., Weihed, P. and Global, VMS Research Project Team (2002) Global comparisons of volcanic-associated massive sulphide districts, In: The timing and location of Major Ore deposits in an evolving orogen, Bundell, D.J., Neubaus, F. And Von QuadT. A. (eds), Geophysical Society of London, Special Publications, 204: 13-37

Al-Shanti, A.M.S. (1969) Exploration of a gossan near Bahrah, in Mineral resources Research, 1967-1968, Saudi Arabian Directorate General of Mineral Resources, p: 19-20.

ARGAS, (1983) Bahrah Geophysical Report: Saudi Arabian Deputy Ministry for Mineral Resources, Open-File Report 83 ARG 07, 17 p., 1 fig., 48 pls.

Bundell, D.J., Neubaus, F. and Von Quad, T.A. (eds), Geophysical Society of London, Special Publications, 204, p: 13-37.

Constable, S.C., Parker, R.L. and Constable, C.G. (1987) Occam's inversion - A practical algorithm for generating smooth models from EM sounding data: Geophysics, 52: 289-300.

Interpex, Ltd. (2007) IX1D v. 3 inversion software, at http://www.interpex.com/

Jacques, A.L., Al-Jehani, A. and Al-Jahdali, N. (2000) General reconnessence of the Bahrah volcanic belt, Makkah Quadrangle, Kingdom of Saudi Arabia, Saudi Geological Survey, Minstry of Petroleum and Mineral Resources, Jeddah, BRGM- TR-99(20), 38p.

Last, B.J., Basahl, M.and Oskoui, R. (1985) Magnetic and VLF electromagnetic surveys of the Bahrah prospect (21/39 D). Ministry of Petroleum an Mineral Resources, Deputy Ministry for Mineral Resources, Jiddah, KSA, Open-File Report DGMR-of-05(35).

Matsah, M.I., Gari, M.H.T., Hegazi, M.A., Amlas, M.A. and Hamimi, Z. (2005) Kinematic and progressive deformational history of Al-Jamoom Pan-African Belt, Western Arabian Shield, Saudi Arabia, Annal.Geol. Survey. Egypt., XXVIII: III-131.

Sanders, R.N. and Abdulhay, G. (1987) Mineral potential of the Bahrah $\mathrm{Cu} / \mathrm{Zn}$ prospect Sa(21/39D): Saudi Arabian Deputy Ministry for Mineral Resources Open-File Report, DGMR-OF-05(40).

Tofig, M.A. and Al-Shanti, A.M. (1984) Geology and mineralization of Bahrah area between. Jiddah and Makkah, in Pan-African crustal evolution of the Arabian-Nubian Sheild I.G.C.P Project 164: King Abdulaziz University, Jeddah, Saudi Arabia, Faculty of Earth Sciences, Bulletin, 6: 553-562.

Tofig, H.A. (1977) Geology and mineralization of Bahrah, Saudi Arabia: Unpublished M.Sc. thesis, Institute of Applied Geology, King Abdulaziz University, Kingdom of Saudi Arabia. 


\section{در اسات جيولوجية وجيوفيزيائية استطلاعية لمنطقة بحرة، منطقة مكة المكرمة - المملكة العربية السعودية}

منصور عبدالله القرني، وهشام الحربي، وعبدالمنعم عبدالفتاح الدجدج، وحمدي إسماعيل حسانين، وهثام محمد القليوبي

قسم الجيوفيزياء - كلية علوم الأرض- جامعة الملك عبدالعزيز

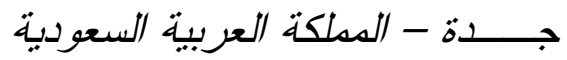

الدستخلص. أدت الدراسات الجيولوجية و الجيوفيزيائية على الجزء الثمالي من مستكثف بحرة، إلى التعرف على نطاق من الطف

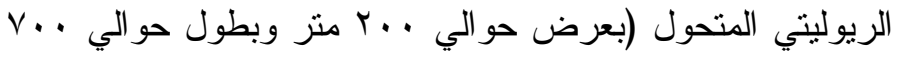
متر) على طول الامتداد الثمالي لنطاق الجوسان الأوسط. يتميز

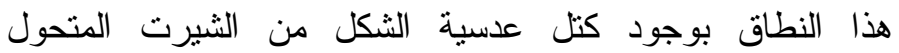
(الجوسان السيليسي)، الباريت الكنلي والينطبق والماجنيتيت. وقد

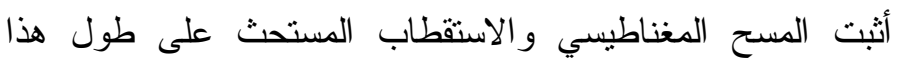

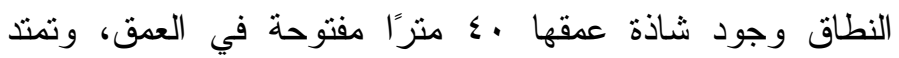

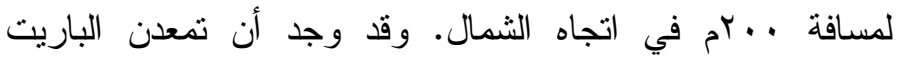

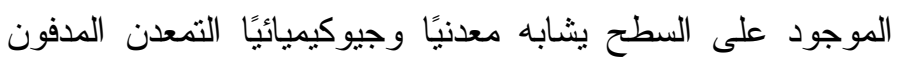

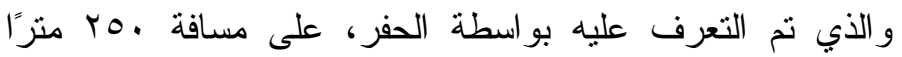

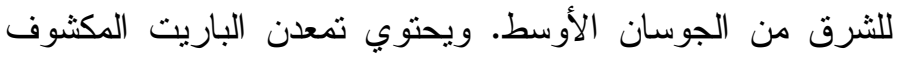

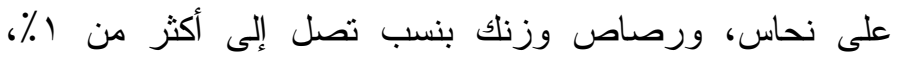

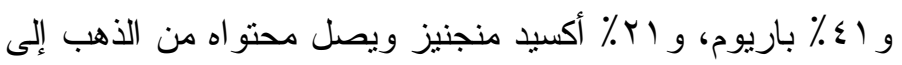

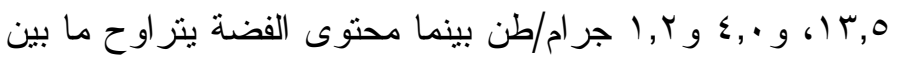


. إحدى العينات. وييدو أن هناك نطاقان للتمعدن (الباريت المكثوف

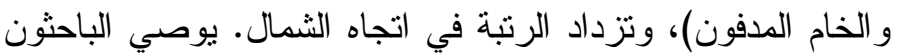

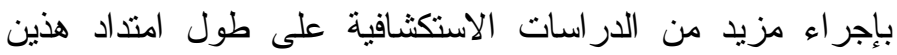

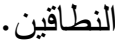

